(C) 2020 International Journal of Nursing and Midwifery Science (IJNMS)

This is an Open Access article distributed under the terms of the Creative Commons Attribution 4.0 International License which permits unrestricted noncommercial use, distribution, and reproduction in any medium, provided the original work is properly cited. http://ijnms.net/index.php/ijnms ORIGINAL RESEARCH

\title{
DETERMINANT ANALYSIS RISK FACTORS INCIDENCE OF HEPATITIS B VIRUS INFECTION AT PREGNANT WOMEN
}

Yuliana $^{1}$, Melyani', Alexander ${ }^{3}$.

1, 2,3 Departement of Midwidery, Academy of Panca Bhakti, Pontianak, , Indonesia.

Email : ${ }^{1}$ yuli.yuliana.uli@gmail.com, ${ }^{2}$ melyani605@gmail.com, ${ }^{3}$ alexis.jk2020@gmail.com,

\begin{abstract}
Hepatitis B is an infectious disease was resulting one maternal death caused liver failure. About 30,965 pregnant women in Indonesia infected hepatitis B virus (HBV) at 2018. Transmission of HBV $95 \%$ are a vertical mother to child through uteroplacental circulation, exposure to amniotic fluid, breast milk and will be new cases of HBV at newborn 3-4 cases per 10,000 live births. The purpose of this study was to analyze risk factors for the incidence of Hepatitis B virus infection in pregnant women at Sungai Durian Public Health Center in 2018-2020. This type of research used case control with a sample of 133 pregnant women with HBsAG reactive (cases) and 532 pregnant women with nonreactive HBsAG (control) by simple random sampling technique. The research instrument used a checklist sheet. The prevalence of Hepatitis B in pregnancy in this research $2.57 \%$. The variables associated with HBV infection were age, parity, LILA, anemia and environment with $p$ value $<0.05$. Maternal age is the dominant factor associated with HBV infection with OR 1.608 because of the risk of infected HBV through saliva and sperm during sexual intercourse, decreased immunity caused pregnancy and medical treatment that can be the entry points for $\mathrm{HBV}$.
\end{abstract}

Keywords

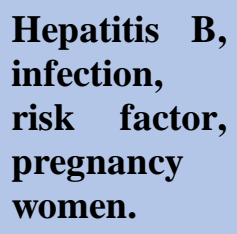

\section{INTRODUCTION}

Indonesia is a country with high Hepatitis B endemicity and the second largest in the South East Asian Region (SEAR) after Myanmar. HBV infection is one of the diseases associated with pregnancy and that increases complications such as rupture of esophageal varices and causing bleeding $(20-25 \%)$ in the second trimester, jaundice and splenic aneurysm rupture if the mother has chronic hepatitis B (Borgia et al. 2012). Hepatitis B has been resulting maternal death from fulminant hepatitis caused by liver failure (V 2001). The prevalence of Hepatitis B Virus (HBV) infection in pregnant women in Indonesia is 29,060 (1.90\%), 348 (2.53\%) in West Kalimantan is higher than the national figure (Kes et al. 2019) while in Sungai Durian Health Center (Kubu Raya Regency) still found 75 cases of HBsAg reactive pregnant women in 2018, 58 cases in 2019 and 12 cases from January to February 2020. HBV can infect pregnant women through bodily 
fluids such as contaminated blood in blood transfusions which are proven to be related with the incidence of HBV infection in 33 pregnant women with a risk of 12,59 times parenterally entering hepatocytes in the form of dane particles (Noubiap et al. 2015). HBV is also found in saliva, tears, semen and vaginal mucus which will infect the host horizontally through the skin and mucosa that is subjected to lesions through sexual activity (Franco et al. 2012). Risky medical actions such as curettage efforts, surgical operations of 4 people (26.67\%) (Access 2015) which opened the way to HBV infection due to tissue injury.

The pattern of HBV transmission in pregnant women to their fetuses with a percentage of $90-95 \%$ (Kementerian Kesehatan Republik Indonesia, 2019) is classified as vertical transmission through uteroplacental circulation using $\mathrm{HBeAg}$ media and HBV DNA (Gozali 2020) because HBV crosses the placenta and induces T-cell tolerance in uterus (Borgia et al. 2012). This is evidenced in a study in China which reported that out of $249 \mathrm{HBsAg}$ positive pregnant women, 167 (67.07\%) were $\mathrm{HBeAg}$ positive, 204 (81.93\%) were HBV DNA positive and only 37 (14.86\%) had HBVDNA> $107 \mathrm{IU} / \mathrm{ml}$. Meanwhile, infants of mothers with positive $\mathrm{HBsAg}$, found 214 (85.94\%) anti-HBs positive babies. There were $12(4.82 \%)$ infants who were HBsAg and HBVDNA positive followed by $\mathrm{HBeAg}$ positive and had HBVDNA> $107 \mathrm{IU} / \mathrm{ml}$ (Ding et al. 2013).

According to the epidimiological concept of Biological Laws, Hepatitis B occurs due to an imbalance between the agent, namely the hepatitis B virus and the host (pregnant women), which occurs in the pathogenesis phase which is influenced by environmental changes (Lapau 2009). The susceptibility of pregnant women to increase HBV ability is influenced by factors of pregnant women age, parity, socioeconomic and living environment, nutritional status (BMI), LILA, gestational age, previous history of abortion, anemia and blood type.

The age at risk for pregnant women is 16-40 years where transmission occurs through sexual activity and the reproductive cycle (pregnancy, childbirth, postpartum and family planning) which is show by a study in the United States pregnant women with Hepatitis B are known to all occur at reproductive age, namely $2572 \%$ ) in the 26 25 year age group, $1038(24 \%)$ aged $\leq 25$ years and $781(18 \%)$ aged $\geq 35$ years (Bajema et al. 2018). Another study in China stated that the age of mothers with Hepatitis B was mostly 247 people (5.64\%) aged $>20$ years and at 4.54 times the risk of being infected with the Hepatitis B virus (Ding et al. 2013). Research in (Lombok) reported $63.4 \%$ of pregnant women with HBV aged 25-34 years (Ismiyati, 2019).

The multiparous and grandemultipara parity status increases the risk of exposure to the Hepatitis B virus because the pregnancy process itself can reduce a mother's immunity so that more pregnancies can reduce maternal immunity so that it can allow the replication of the Hepatitis B virus which may not be detected in the first pregnancy (Kolawole et al. 2012 ). Research reports that pregnant women infected with HBV are multiparous mothers (61.82\%) (China) (Huang et al. 2014), 11 people $(46.67 \%), 23$ people $(20.7 \%)$ (Nigeria) (Access 2015) (Kolawole et al. 2012).

Nutritional status as assessed based on the BMI value is an important determinant of the immune response. Epidemiological and clinical studies show that malnutrition inhibits immune responses and increases the risk of infectious diseases. The study reported the BMI values of pregnant women infected with Hepatitis B 
67 people (BMI 25-29.9), 35 people (BMI $<18.5$ ) and 3 people (BMI $\geq 30$ ) (Cui et al. 2016). LILA is an indicator of nutritional disorders, namely Chronic Energy Deficiency (KEK) in pregnant women which is assessed by measuring the circumference of the mother's upper arm during pregnancy examinations. The relationship between the size of LILA and the incidence of HBV infection in pregnant women has an indirect effect on anemia, which later on anemia will trigger bleeding during childbirth, thereby increasing the chance of blood transfusion, which is the entry point for the hepatitis B virus into the body of pregnant women. Research on the relationship between LILA and KEK with the incidence of hepatitis B virus infection has not been widely conducted.

Anemia is a common complication of chronic liver disease due to acute and chronic gastrointestinal bleeding and secondary hypersplenism of portal hypertension. The study reported that the characteristics of pregnant women with hepatitis B had the lowest $\mathrm{Hb}$ level at delivery of $8.2 \mathrm{~g} \%$ and the highest was 15 g\% (V 2001). The earlier it is known, the lower the transmission to the fetus or baby that is born. Several studies found HBV infection in mothers of 21 people (17.4\%) (Nigeria) (Kolawole et al. 2012), 99.5\% (Iran) (Afzali et al. 2015) occurred in the third trimester of pregnancy. The highest parity rate found in pregnant women with HBV infection was 9 (V 2001).

History of abortion is one of the risks found in pregnant women in several studies that are associated with medical treatment, tissue injury and a history of blood transfusions. Research in Iran found $5.72 \%$ of HBV cases in pregnant women with a risk of previous abortion (Afzali et al. 2015). A person's blood type interacts with the immune system, which can affect a person's risk of certain diseases. Non-O groups are more at risk of developing inflammation.

The environment where people with Hepatitis B virus infection in developing countries live mostly come from rural areas (Ugbebor et al., 2011). Results of a study in Cameroon $10.2 \%$ of pregnant women with hepatitis B came from rural areas (Noubiap et al. 2015). Research in Iran stated that $82.29 \%$ came from urban areas, but statistically this is not directly related to the cause of infection transmission (HBV) (Afzali et al. 2015).

\section{METHOD}

This type of research is a case control, which is an analytical (observational) study that measures risk factors for hepatitis B infection first, then measures the incidence of infection itself with a retrospective approach. The population in this study were all pregnant women who performed pregnancy examinations and carried out rapid diagnostic tests for the period January 2018- March 2020 as many as 1,566 people. The sample in this study was divided into case groups, namely HBsAG reactive pregnant women and controls (HBsAG nonreactive pregnant women). As for the number of samples in the case group was 133 people and the control group was taken 4 times, namely 532 people.

The sampling technique for the control group was taken randomly / simply by making a list according to the total population of pregnant women who were not infected with Hepatitis B as much as 1,566, then making a small lottery sheet for all names and taking samples by removing 532 samples from the lottery. The instrument used to collect respondent data used a check list sheet which contains all components of risk factors for Hepatitis B infection in pregnant women. Types of data collected are secondary data by collecting medical records 
listed in the KIA records of Sungai Durian Health Center.

Data Analysis was carried out in three stages starting from univariate analysis to see the distribution of risk factors for the case and control groups, then continued by looking at the relationship between variables with chi square and finally determining the dominant risk factor for Hepatitis B infection with multiple logistic regression.

\section{RESULTS}

Tabel 1. Respondents Charateristic Frequency Distribution Based on Age, Parity, Nutritional status (BMI), LILA Size, Gestational age, History of Abortion, Anemia, Blood type and residence

\begin{tabular}{clllll}
\hline Variable & \multicolumn{2}{l}{ Case } & \multicolumn{3}{c}{ Control } \\
\cline { 2 - 5 } & n & $\%$ & \multicolumn{2}{c}{$\mathbf{~ N}$} & \% \\
\hline Age & & & & \\
\hline $16-40$ & 11 & 88, & 516 & 97,0 & \\
& 8 & 7 & & \\
\hline$<16$ & 15 & 11, & 16 & 3,0 & \\
and $>$ & & 3 & & \\
40 & & & & \\
\hline
\end{tabular}

\begin{tabular}{|c|c|c|c|}
\hline Parity & & & \\
\hline $\begin{array}{l}(<1 \\
\text { child })\end{array}$ & 93 & $\begin{array}{l}69, \quad 317 \\
9\end{array}$ & 59,6 \\
\hline $\begin{array}{l}(\geq \\
\text { 1child })\end{array}$ & 40 & $\begin{array}{l}30,215 \\
1\end{array}$ & 40,4 \\
\hline Nutritional S & tatus & & \\
\hline $\begin{array}{l}\text { Body } \\
\text { Mass } \\
\text { Index } \\
(<18 \\
5 \text { and } \\
>25)\end{array}$ & 78 & $\begin{array}{l}58,265 \\
6\end{array}$ & 49,8 \\
\hline $\begin{array}{c}\text { Body } \\
\text { Mass } \\
\text { Index } \\
(18,5 \\
-25)\end{array}$ & 55 & $\begin{array}{l}41,267 \\
4\end{array}$ & 50,2 \\
\hline $\begin{array}{r}\text { Size of } \\
(\text { LILA) }\end{array}$ & & arm ci & \\
\hline
\end{tabular}

\begin{tabular}{cllll}
\hline $\begin{array}{c}\text { (LILA } \\
<23,5)\end{array}$ & 3 & 2,3 & 56 & 10,5 \\
\hline $\begin{array}{c}\text { LILA } \\
\geq 23,5)\end{array}$ & 13 & 97, & 476 & 89,5 \\
& 0 & &
\end{tabular}

\section{Gestational Age}

\begin{tabular}{rlllll}
\hline$<$ & 37 & 11 & 88, & 472 & 88,7 \\
week & & 8 & 7 & & \\
\hline$(37 \quad \&$ & 15 & 11, & 60 & 11,3 \\
$>42$ week $)$ & & 3 & &
\end{tabular}

\section{History of Abortion}

\begin{tabular}{lllll}
\hline Yes & 9 & 6,8 & 47 & 8,8 \\
\hline No & 12 & 93, & 485 & 91,2 \\
& 4 & 2 & &
\end{tabular}

\begin{tabular}{rllll}
\hline Anemia & & & \\
\hline Yes & 18 & 13, & 117 & 22,0 \\
& & 5 & & \\
\hline No & 11 & 86, & 415 & 78,0 \\
& 5 & 5 & & \\
& & &
\end{tabular}

\begin{tabular}{|c|c|c|c|}
\hline \multicolumn{4}{|l|}{ Blood Type } \\
\hline Type $\mathrm{O}$ & 46 & $\begin{array}{l}34, \quad 186 \\
6\end{array}$ & 35,0 \\
\hline Type A & 24 & $\begin{array}{ll}18 . & 116 \\
0 & \end{array}$ & 21,8 \\
\hline Type B & 46 & $\begin{array}{l}34.188 \\
6\end{array}$ & 35,3 \\
\hline AB & 17 & $\begin{array}{l}12.42 \\
8\end{array}$ & 7,9 \\
\hline \multicolumn{4}{|c|}{ Residental Environment } \\
\hline $\begin{array}{l}\text { Limbu } \\
\text { ng } \\
\text { Vilage }\end{array}$ & 63 & $\begin{array}{ll}47, & 191 \\
4 & \end{array}$ & 35,9 \\
\hline $\begin{array}{l}\text { Other } \\
\text { Vilage }\end{array}$ & 70 & $\begin{array}{l}52, \quad 341 \\
6\end{array}$ & 64,1 \\
\hline
\end{tabular}

Based on table 1 above, the proportion of pregnant women aged 16-40 years is 118 people $(88.7 \%)$ in cases and 516 people $(97 \%)$ in controls, with a different proportion of $8.3 \%$. The proportion of parity $<1$ child was 82 people $(61.7 \%)$ in cases and 317 people $(59.6 \%)$ in controls, with a difference of $2.1 \%$. Proportion of abnormal nutritional status with Body Mass Index (BMI) $<18.5->25$ are 78 people $(58.6 \%)$ in 
cases and 265 people (49.8\%) in controls, with a different proportion of $8.8 \%$. The proportion of normal upper arm circumference $\geq 23.5130$ people $(97.7 \%)$ in cases and 476 people (89.5\%) in controls, with a different proportion of $8.2 \%$. The proportion of pregnant women without a history of previous abortion was 124 $(93.2 \%)$ in cases and $485(91.2 \%)$ in controls, with a difference of $2 \%$. The proportion of pregnant women without anemia (hemoglobin level $\geq 11 \mathrm{gr} \%$ ) was 115 people $(86.5 \%)$ in cases and 415 people (78.3\%) in controls, with a different proportion of $8.2 \%$. The proportion of pregnant women with blood type B was 46 $(34.6 \%)$ in cases and $188(35.3 \%)$ in controls, with a difference in proportion of $0.7 \%$. The proportion of pregnant women who came from the urban living environment (in the village of limbung) was 70 people $(52.6 \%)$ in the case and as many as 341 people $(64.1 \%)$ in the control, so the difference in proportion was $11.5 \%$. The proportion of gestational age ( $<37$ weeks) was 118 people (88.7\%) in cases and 472 people $(88.7 \%)$ in controls with a different proportion of $0 \%$ or with the same proportion between cases and controls.

Tabel 2 Assosiated Between Risk

Factors with the Incidence of

Hepatitis B Virus Infection in Pregnant Women

\begin{tabular}{|c|c|c|c|}
\hline $\begin{array}{l}\text { Vari } \\
\text { able }\end{array}$ & Case & $\begin{array}{l}\text { Cont } \\
\text { rol }\end{array}$ & $\begin{array}{l}\text { Diffe } P \\
\text { rent Val OR }\end{array}$ \\
\hline & n $\%$ & n $\%$ & $\begin{array}{l}\text { Prop ue } \\
\text { ortio } \\
\text { n }\end{array}$ \\
\hline
\end{tabular}

\begin{tabular}{rlllllll}
\hline Age & & & & & & & \\
\hline 1 & 1 & 8 & 5 & 9 & $8,3 \%$ & & 0,2 \\
6 & 1 & 8. & 1 & 7. & & 0, & 44 \\
- & 8 & 7 & 6 & 0 & & 00 & $(0$, \\
4 & & & & & & 0 & 11 \\
0 & & & & & & & $7-$ \\
\hline
\end{tabular}

\begin{tabular}{llllll}
\hline & 1 & 1 & 1 & 3. & 0,5 \\
1 & 5 & 1. & 6 & 0 & $07)$ \\
6 & & 3 & & & \\
$\mathrm{a}$ & & & & & \\
$\mathrm{n}$ & & & & & \\
$\mathrm{d}$ & & & & & \\
$>$ & & & & & \\
4 & & & & & \\
0 & & & & &
\end{tabular}

\begin{tabular}{|c|c|c|c|c|c|c|c|}
\hline \multicolumn{8}{|c|}{ Parity } \\
\hline \multirow{3}{*}{$\begin{array}{l}\quad \geq \\
1 \\
\text { child }\end{array}$} & 9 & 6 & 3 & 5 & 10,3 & 0 & 1,5 \\
\hline & 3 & 9. & 1 & 9. & $\%$ & 03 & 77 \\
\hline & & 9 & 7 & 6 & & 6 & (1, \\
\hline \multirow[b]{2}{*}{1} & 4 & 3 & 2 & 4 & & & 04 \\
\hline & 0 & 0 . & 1 & 0 . & & & 7- \\
\hline \multirow{2}{*}{ child } & & 1 & 5 & 4 & & & 2,3 \\
\hline & & & & & & & 74) \\
\hline
\end{tabular}

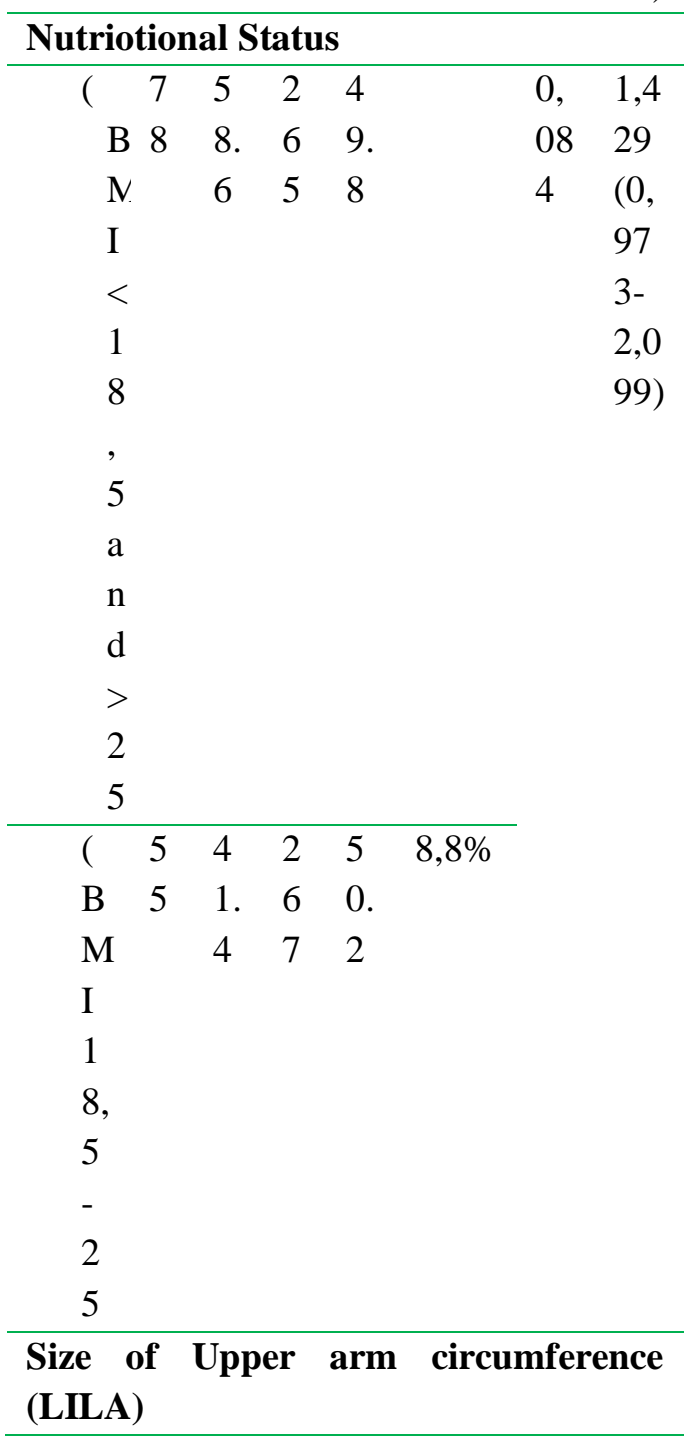




\begin{tabular}{rlllllll}
\hline L & 3 & 2. & 5 & 1 & & 0, & 0,1 \\
ILA & & & 6 & 0. & & 00 & 96 \\
$<23$, & & & & 5 & & 5 & $(0$, \\
$5 \mathrm{~cm}$ & & & & & & & 06 \\
& 1 & 9 & 4 & 8 & $8,2 \%$ & & $0-$ \\
LIL & 3 & 7. & 7 & 9. & & & 0,6 \\
$\mathrm{~A}$ & 0 & 7 & 6 & 5 & & & $37)$ \\
$\geq 23$, & & & & & & & \\
$5 \mathrm{~cm}$ & & & & & & & \\
& & & & & & &
\end{tabular}

\begin{tabular}{llllllll}
\multicolumn{9}{c}{ Gestational Age } \\
\multicolumn{1}{c}{$<$} & 1 & 8 & 4 & 8 & $0 \%$ & 1, & 1,0 \\
37 & 1 & 8. & 7 & 8. & & 00 & 00 \\
week & 8 & 7 & 2 & 7 & & 0 & $(0$, \\
\cline { 1 - 5 } & 1 & 1 & 6 & 1 & & & 54 \\
$7 \&>$ & 5 & 1. & 0 & 1. & & & $8-$ \\
42 & & 3 & & 3 & & & 1,8 \\
week & & & & & & $23)$
\end{tabular}

\section{History of Abortion}

\begin{tabular}{|c|c|c|c|c|c|c|c|c|}
\hline \multirow[b]{2}{*}{ es } & Y & 9 & 6. & 4 & 8. & & 0 & 0,7 \\
\hline & & & 8 & 7 & 8 & & 55 & 49 \\
\hline \multirow{5}{*}{0} & $\mathrm{~N}$ & 1 & 9 & 4 & 9 & $0 \%$ & 3 & $(0$, \\
\hline & & 2 & 1. & 8 & 1. & & & 35 \\
\hline & & 4 & 2 & 5 & 2 & & & 7- \\
\hline & & & & & & & & 1,5 \\
\hline & & & & & & & & 70) \\
\hline
\end{tabular}

\begin{tabular}{|c|c|c|c|c|c|c|c|}
\hline \multicolumn{8}{|c|}{ Anemia } \\
\hline $\mathrm{Y}$ & 1 & 1 & 1 & 2 & & 0 & 0,5 \\
\hline \multirow[t]{2}{*}{ es } & 8 & 3. & 1 & 2 & & 04 & 55 \\
\hline & & 5 & 7 & & & 0 & $(0$, \\
\hline $\mathrm{N}$ & 1 & 8 & 4 & 7 & $7,5 \%$ & & 32 \\
\hline \multirow[t]{3}{*}{ o } & 1 & 6. & 1 & 8 & & & 4- \\
\hline & 5 & 5 & 5 & & & & 0,9 \\
\hline & & & & & & & 50) \\
\hline \multicolumn{8}{|c|}{ Blood Type } \\
\hline $\mathrm{T}$ & 4 & 3 & 1 & 3 & $0,3 \%$ & 1, & 0.9 \\
\hline ype & 6 & 4. & 8 & 4, & & 00 & 84 \\
\hline $\mathrm{O}$ & & 6 & 6 & 9 & & 0 & $(0$. \\
\hline $\mathrm{T}$ & 8 & 6 & 3 & 6 & & & 66 \\
\hline ype & 7 & 5. & 4 & 5. & & & $0-$ \\
\hline non & & 4 & 6 & 1 & & & 1.4 \\
\hline $\mathrm{O}$ & & & & & & & 66) \\
\hline
\end{tabular}

\section{Residental Environment}

\begin{tabular}{llllllll}
\hline $\mathrm{Li}$ & 6 & 4 & 1 & 3 & & 0, & 1,6 \\
$\mathrm{mb}$ & 3 & 7. & 9 & 5. & & 02 & 07 \\
un & & 7 & 1 & 9 & & 0 & $(1$, \\
$\mathrm{g}$ & & & & & & & 09 \\
$\mathrm{Vil}$ & & & & & & & $5-$ \\
age & & & & & & & 2,3 \\
\cline { 1 - 3 } Ot & 7 & 5 & 3 & 6 & 11,5 & & $58)$ \\
her & 0 & 2. & 4 & 4. & $\%$ & & \\
Vil & & 6 & 1 & 1 & & & \\
age & & & & & & & \\
\hline
\end{tabular}

Based on Table 2 above, it was found the results of bivariate analysis was obtained 5 variables with $p$ value $<0.05$, which were statistically significant related to the incidence of hepatitis B virus infection in pregnancy, such as the age variable with a $\mathrm{p}$ value of 0.000 and OR 0.244 meaning that pregnant women aged $<16$ and $>40$ years $76 \%$ were spared. Hepatitis B virus infection than pregnant women aged 16-40 years. Parity variable with p-value 0.036 and OR 1.577 means that pregnant women with parity $\geq 1$ child are 1.58 times more likely to be infected with Hepatitis B virus than pregnant women with parity $<1$ child. Variable upper arm circumference (LILA) with $p$ value of 0.005 and OR 0.196 means that pregnant women with LILA $\geq 23.5 \mathrm{~cm}$ $80 \%$ avoid hepatitis B virus infection compared to LILA $<23.5 \mathrm{~cm}$. Anemia variable with a $p$ value of $0.04(\mathrm{P}<0.05)$ and OR 0.555 means that pregnant women without anemia are $44.5 \%$ prevented from being infected with the hepatitis $B$ virus compared to mothers with anemia. The variable of residence with a $p$ value of 0.020 and OR 1.607 means that pregnant women from the environment around Limbung Village are protected by 1.6 times greater than contracting the Hepatitis B virus than pregnant women who come from the environment outside Limbung Village. The variables that were not statistically related to the incidence of hepatitis B virus infection in 
pregnant women in this study were nutritional status ( $\mathrm{p}$ value 0.084 ), gestational age ( $\mathrm{p}$ value 1,000 ), variable abortion history ( $p$ value 0.553 ) and blood group variables ( $p$ value. value 1,000 ). This means that there is no relationship between nutritional status, gestational age, history of abortion and blood type with the incidence of Hepatitis B virus infection in cases and controls.

Tabel 3 Result of Multivariate Analyze of

Risk Factors Incidence Of Hepatitis B Virus Infection

\begin{tabular}{lllll}
\hline Variable & P & Ne & Old & Chang \\
& val & w & OR & ed of \\
& ue & OR & & OR
\end{tabular}

Expenditure of the parity variable

$\begin{array}{cllll}\text { Age } & 0.01 & 1.63 & 1.62 & 0,6 \\ & 5 & 4 & 4 & \\ \text { Nutriti } & 0.20 & 1.29 & 1.25 & 2,7 \\ \text { nal Status } & 3 & 3 & 9 & \\ \text { Upper } & & & & 4,5 \\ \text { rm } & 0.01 & 0.21 & 0.22 & \\ \text { circumfere } & 1 & 3 & 3 & \\ \text { ce } & & & & \\ \text { LILA) } & & & & \\ \text { Anemi } & 0.13 & 0.66 & 0.66 & 1,0 \\ & 8 & 0 & 7 & \\ \text { Reside } & & & & 4,8 \\ \text { tal } & 0.00 & 0.27 & 0.29 & \\ \text { Environme } & 1 & 6 & 0 & \\ \text { (1) } & & & & \\ \text { Expenditure } & & & \end{array}$

Expenditure of the Nutritional Status variable

\begin{tabular}{rllll}
\hline \multicolumn{1}{c}{ Age } & 0.01 & 1.62 & 1.63 & 0,9 \\
& 6 & 0 & 4 & \\
\multicolumn{1}{r}{ Upper } & & & & 4,2 \\
$\begin{array}{l}\text { arm } \\
\text { circumfere }\end{array}$ & 0.00 & 0.20 & 0.21 & \\
nce & 9 & 4 & 3 & \\
(LILA) & & & & \\
\hline Anemi & 0.11 & 0.64 & 0.66 & 2,4 \\
a $\quad$ & 6 & 4 & 0 & \\
\hline Reside & 0.00 & 0.26 & 0.27 & 2,8 \\
ntal & 1 & 8 & 6 & \\
\hline
\end{tabular}

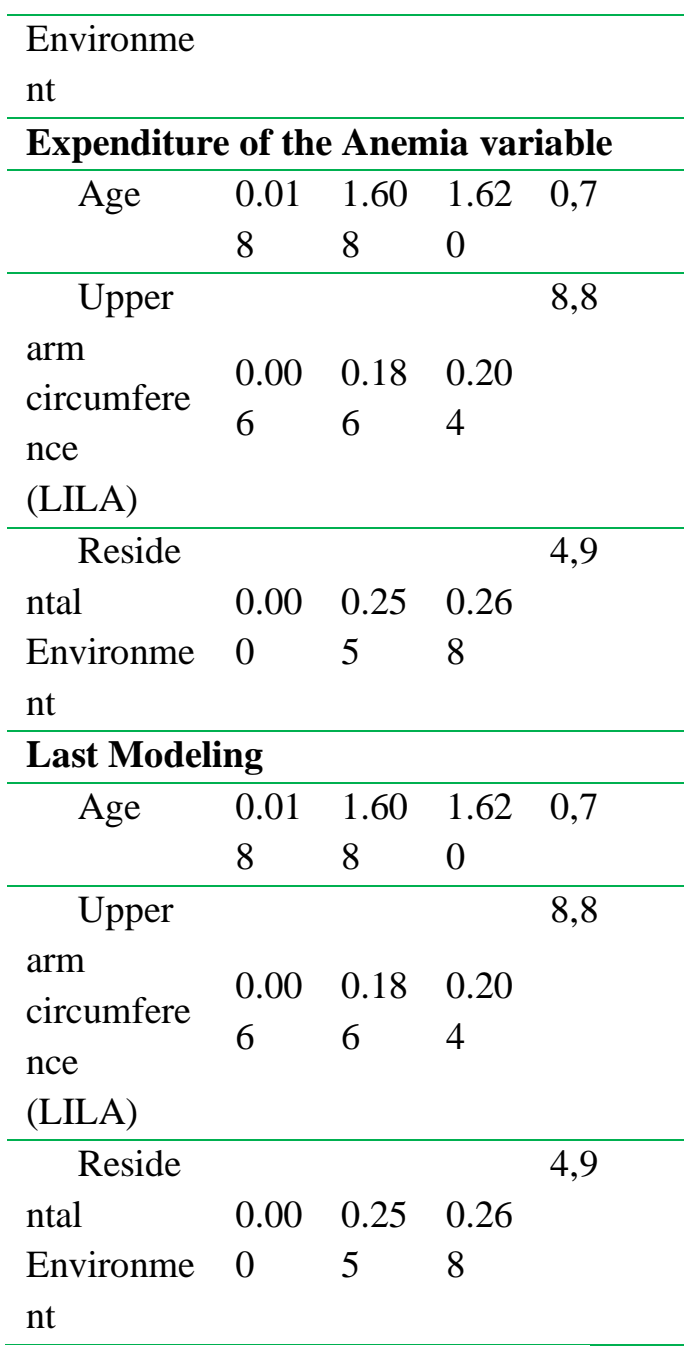

Based on Table 3 above, it was found the dominant variable for hepatitis B virus infection in pregnant women in this research was age (1.608) with the largest OR, meaning that respondents aged 16-40 years had 1.6 risk of being infected with the hepatitis B virus compared to pregnant women aged $<16$ years and $>40$ years.

\section{DISCUSSION}

a. Incidence of Hepatitis B Infection in Pregnancy

The incidence of hepatitis B virus infection in pregnant women is diagnosed through a blood test that looks for one antigen - HBsAg (surface antigen, or surface, hepatitis B) and two 
antibodies - anti-HBs (antibody to HBV surface antigen) and anti-HBc (antibody against HBV surface antigen). core, or core, VHB) (Gozali, 2020). The diagnosis of Hepatitis B in this study was based on the results of the HBSAG examination on pregnant women who had their pregnancy checked at the Sungai Durian Public Health Center in accordance with the theory presented by (Lesmana, n.d.) which states that Hepatitis B is diagnosed by a blood test that looks for certain antigens (hepatitis B virus fragments). and antibodies (made by the immune system in reaction to HBV). The initial blood test for the diagnosis of HBV infection looks for one antigen - HBsAg (surface antigen, or surface, hepatitis B) and two antibodies - anti-HBs (antibody to HBV surface antigen) and anti-HBc (antibody to core, or core, antigen) VHB).

The prevalence of Hepatitis B incidence in pregnant women at Sungai Durian Health Center based on the results of the study was $2.57 \%$ (133 cases out of 5166) pregnant women was higher than the prevalence of Hepatitis $\mathrm{B}$ in pregnant women in Indonesia as much as $1.90 \%$ from $38.44 \%$ Rapid Diagnostic tests and $2.53 \%$ of cases from $14.19 \%$ of pregnant women who were tested for their HbSAg status in West Kalimantan Province (Kes et al., 2019).

The prevalence of Hepatitis B incidence in pregnant women in this study was lower than the prevalence of Hepatitis B among pregnant women in a study in Jakarta of 5,000 pregnant women in 2013 obtained blood samples with HBsAg (+) in 159 mothers (3.18\%), where $98(62 \%)$ of 159 mothers had Hepatitis B virus DNA (Anna, 2015). The difference in prevalence rates is due to differences in the characteristics of the sample (pregnant women) in Jakarta and in Kubu Raya, of course different, namely between the people in the capital city and the province both from information on Hepatitis B is easier to obtain in Jakarta with relatively high public education so that it has a positive effect on understanding. About the need for early detection of HBsAG status can be seen from the number of samples that are 23 times more than this study. The availability of health facilities that have rapid diagnostic test services in Jakarta also affects the high participation of pregnant women in early detection of hepatitis B virus infection in early pregnancy.

The prevalence of Hepatitis B incidence in this study was lower than the prevalence of Hepatitis B incidence at the Benin Teaching Hospital (UBTH) Nigeria, namely $12.5 \%$ (720 infected mothers from 5760 pregnant women in the period October 2009-October 2010 (Ugbebor et al., 2011). The difference in prevalence rates is due to differences in transmission patterns and endemicity levels between Indonesia and Nigeria as well as different sociodemographies and possible sources of infection. To reduce the number of complications or complications for pregnant women or their fetuses, it is necessary to make early detection of the presence of the Hepatitis B virus in the patient's body by examining $\mathrm{HBsAg}$, which is a type of antigen contained in the packaging part of the Hepatitis B virus that can be detected in infected body fluids (Wijayanti, 2016).

The prevalence of Hepatitis B virus infection in certain populations is influenced by the characteristics of the 
study site and the number of samples. Although early detection of HBsAG status for pregnant women had been carried out at Sungai Durian Public Health Center, the Anti HBs and anti$\mathrm{HBc}$ examinations were not carried out in this study due to limited facilities and infrastructure at the Puskesmas and further handling of Hepatitis B cases that were emergency was referred to the Provincial Hospital The diagnosis, which is limited to checking the HBSAg status alone, in this study, of course, cannot know with certainty the extent of the mother's inflammatory liver condition and its effect on the fetus that is conceived and will be born at a later date so that the potential risk of transmission remains.

\section{b. Corelated age with hepatitis $B$ virus infection in pregnant women}

Result of this research show the proportion of pregnant women aged 1640 years was $118(88.7 \%)$ in cases and $516(97 \%)$ in controls, with a different proportion of $8.3 \%$. Age variable were statistically significant related to the incidence of hepatitis B virus infection in pregnancy with a $p$ value of 0.000 and OR 0.244 meaning that pregnant women aged $<16$ and $>40$ years $76 \%$ were spared Hepatitis B virus infection than pregnant women aged 16-40 years. The results of this study are in line with research in (Lombok) reported $63.4 \%$ of pregnant women with HBV aged 25-34 years (Faizaturrahmi et al., 2018)

The results of this study are in line with several studies in various countries, including research in China which states that the age of mothers who experience the most hepatitis B is 247 people $(5.64 \%)$ at the age $>20$ years and at 4.54 times the risk of being infected with
HBV compared to mothers at age <20 year (Ding et al., 2013). At United States, 4391 pregnant women with unknown hepatitis occurred at the age of the group, namely 2572 (59\%) in the 2625 year age group, 1038 (24\%) aged $\leq$ 25 years and $781(18 \%)$ aged $>35$ years (Bajema et al., 2018). Research in Nigeria as many as $30(12.2 \%)$ occurred in the age group 25-34 years, (Aj et al. 2015).. Recent studies in Africa suggest that the relatively high prevalence of $\mathrm{HBsAg}$ in pregnant women is caused by sexual contact or contact. Transmission through the method above is because the hepatitis B virus is not in the blood of a patient who has been infected with the Hepatitis B virus, but can also be found in the body such as saliva, tears, semen and vaginal mucus (Franco et al., 2012). An investigation reports that a person infected with hepatitis B found specific antibodies in the age group 25-29 years and 30-34 years (Kolawole et al., 2012).

Age structure is an important demographic aspect to observe because it can reflect or reflect the individual's state of symptoms and disease severity. (Hasyimi Muhamad, 2012). Age also includes part of the variable of people who serve with circumstances such as a reflection of behavioral behavior, behavior with changes in body resistance or immunity (Lapau, 2009). The age at risk for pregnant women to infected Hepatitis B Virus is $16-40$ years, which is a phase of life that is prone to infection through sexual activity and the cycle because HBV is also found in saliva, tears, semen and vaginal mucus which will infect the host horizontally through the skin and mucosa that is experiencing lesions (Franco et al., 2012) .

All age data in several studies above and in line with this study indicate 
that the age at risk for a woman to be infected with the Hepatitis B virus is between the ages of 16-40 years, at which age a woman is classified as reproductive age and most of them are married, in their life cycle. a married woman will get pregnant, give birth and breastfeed, in every phase of this life women are very vulnerable to infection. At the age of 40 years, women's sexual activity usually decreases and is less likely to get pregnant and give birth and even prefer to use effective contraception.

In this study as many as 11 pregnant women with Hepatitis B aged $<20$ years, if the respondent's menopause age is above 50 years of age, the period of sexual activity of the mother is still 30 years old and the possibility of pregnant women returning is still very high and can transmit to the baby vertical, to the husband horizontally. This is in line with the opinion of Setyohadi (2016) which states that the younger a person is infected with the Hepatitis B virus, the greater the percentage of infection develops chronic, i.e. if a person is infected from birth, the probability of becoming chronic hepatitis $\mathrm{B}$ is estimated at $90 \%$, the older the person is infected. HBV, the lower the percentage of suffering from chronic hepatitis $B$.

c. Corelated Parity with hepatitis B virus infection in pregnant women

Result of this research show the proportion of parity $<1$ child was 82 people (61.7\%) in cases and 317 people $(59.6 \%)$ in controls, with a difference of $2.1 \%$, parity variable were statistically significant related to the incidence of hepatitis B virus infection in pregnancy with p-value 0.036 and OR 1.577 means that pregnant women with parity $\geq 1$ child are 1.58 times more likely to be infected with Hepatitis B virus than pregnant women with parity $<1$ child.

The results of this study are in line with research conducted by Merry, 2001 at RSUP Dr. Kariadi Semarang for the period 1997-1999, it is known that 89 pregnant women with Hepatitis B found the highest parity rate of 9 or belonging to the grande multi para category or parity $\geq 1$, possibly the source. infection acquired 29 mothers (32.6\%) had a history of frequent injections, 14 mothers (15.7\%) had a history of surgery $(\mathrm{V}, 2001)$.

The results of this study are in line with several studies which reported that pregnant women infected with HBV were multiparous mothers $(61.82 \%)$ (China) (Huang et al., 2014), 11 people (46.67\%), 23 people (20.7\%). (Nigeria) (Access, 2015) (Kolawole et al. 2012), $55 \%$ with parity status $\geq 1$ child (United States) (Bajema et al., 2018), 57.7\% with parity $\geq 2$ with $\mathrm{p}$ value 0.001 (Indonesia) (Faizaturrahmi et al., 2018). Although it is not directly related as a causal relationship, high parity $\geq 1$ has less good health conditions than low parity $<1$ child. The higher the parity, the greater the possibility of HBV infection in pregnant women because every delivery has the risk of complications and complications that allow for various actions, such as induction of labor by infusion in the first stage, episiotomy in stage II, manual placenta, internal bimanual compression and externa in stage III, heacting in stage IV. All these actions are of course an entry point for Hepatitis $B$ virus infection.

The high parity of $\geq 1$ child in this study was due to the fact that most of the respondents / pregnant women 
were 16-40 years old, where at this age almost all couples planned pregnancy. The status of multiparous parity and grandemultipara ( $\geq 1$ child) increases the risk of exposure to the Hepatitis B virus because the pregnancy process itself can reduce a mother's immunity so that more pregnancies can reduce maternal immunity so that it can allow the replication of the Hepatitis B virus which may not be detected in the first pregnancy (Kolawole et al. 2012).

High parity also potential for horizontal transmission from one person with the disease to another. This pattern can occur in two ways, namely transmission through the skin and mucosa. The hepatitis B virus cannot penetrate intact skin, so infection can occur by penetrating the skin by a needle puncture or other device contaminated with infective material or through contact between the infective material and skin that has undergone changes / lesions (Mandala K, 2006).

d. Corelated Nutriotional status with hepatitis $B$ virus infection in pregnant women

Result of this research show the proportion of abnormal nutritional status with Body Mass Index (BMI) $<18.5$ - > 25 are 78 people $(58.6 \%)$ in cases and 265 people $(49.8 \%)$ in controls, with a different proportion of $8.8 \%$. Nutritional status variable were not statistically significant related to the incidence of hepatitis B virus infection in pregnancy with $\mathrm{p}$-value 0.084 . The results of this study are in line with research which found that pregnant women with positive HBsAg status had a significantly lower body weight and height than controls, so that a person's nutritional status was related to hepatitis B status (Acholder, 2013)
This study is in line with studies in China which reported abnormal BMI values in pregnant women infected with Hepatitis B 67 people (BMI 25-29.9), 35 people (BMI <18.5) and 3 people (BMI $\geq 30$ ) (Cui et al., 2016). The results of this study are consistent with epidemiological and clinical studies showing that malnutrition inhibits the immune response and increases the risk of infectious diseases. In 1968, the World Health Organization (WHO) published the WHO Monograph on Nutrition-infection Interactions. This publication is the result of a collaboration between Nevin S. Scrimshaw, Carl Taylor, and John Gordon (Scrimshaw et al. 1968). In this publication, Scrimshaw and colleagues for the first time argue that the link between malnutrition and infection is synergistic. That is, malnutrition aggravates infectious diseases, as well as infections exacerbate malnutrition (Albiner, 2006)

This study is different with Huang Xi's research on 6,195 respondents in China, it was found that 461 pregnant women were infected with Hepatitis B and the highest BMI was that pregnant women who were infected with the Hepatitis B Virus when they first performed antenatal care with a BMI value of 18.5-24.9 were 322 pregnant women $(69.85 \%)$ and the lowest was mothers with BMI> 25 as many as 54 people (11.71\%) (Huang et al., 2014). Although the BMI in this study is normal, the BMI of a person, especially pregnant women, of course will affect immunity or immunity, with an imperfect immune status, it is likely that the body's reaction when infected with the virus will be weak in defending and making it easier for the virus to develop and become a disease. 
Nutritional status as assessed based on the Body Mass Index (BMI) value is an important determinant of the immune response. Epidemiological and clinical studies show that malnutrition inhibits immune responses and increases the risk of infectious diseases. The socio-economic level also plays a role in determining a person's health status, in this case the family's purchasing power. The ability of a family to buy food, among others, depends on the size of the family's income, the price of the food itself, and the level of processing of land and yard resources (Syafiq, 2009)

Low family socioeconomic is closely related to family health and a high possibility of Hepatitis B infection. Because with low incomes, families are more likely to prioritize expenditures on basic needs such as food and are more likely not to set aside the income received for health efforts, both promoted by providing good nutrition, diverse food and preventive measures, for example by hepatitis B vaccination, general check-ups or examinations routine health.

e. Corelated Upper arm circumference (LILA) with hepatitis B infection

Upper arm circumference (LILA) is an indicator of nutritional disorders, namely Chronic Energy Deficiency (KEK) in pregnant women. Result of this research show the proportion of normal upper arm circumference $\geq 23.5$ 130 people $(97.7 \%)$ in cases and 476 people $(89.5 \%)$ in controls, with a different proportion of $8.2 \%$. Variable upper arm circumference (LILA) were statistically significant related to the incidence of hepatitis B virus infection in pregnancy with p-value 0.005 and OR 0.196 means that pregnant women with LILA $\geq 23.5 \mathrm{~cm} 80 \%$ avoid hepatitis B virus infection compared to LILA $<23.5$ $\mathrm{cm}$.

The relationship between LILA size and the incidence of HBV infection in pregnant women has an indirect effect on anemia, which in turn causes bleeding during delivery, thereby increasing the chances of blood transfusions that are the entry points for the hepatitis B virus into the body. pregnant women. There are not many studies on the relationship between LILA or KEK and the incidence of hepatitis $B$ virus infection.

Although it is not related to the cause and effect of pregnancy and Hepatitis B virus infection, the impact of Hepatitis B virus transmission in pregnancy is very dependent on the time when HBV was detected in the mother. Conclusion the pregnancy are not directly related to Hepatitis B virus infection, however, the longer the mother is detected, the greater the impact on pregnancy and transmission of the Hepatitis B virus. The earlier it is known, the lower the transmission to the fetus or the baby is close to it. Several studies found HBV infection in mothers of 21 people (17.4\%) (Nigeria) (Kolawole et al. 2012), 99.5\% (Iran) (Afzali et al., 2015) occurred in the third trimester of pregnancy. The highest parity rate found in pregnant women with HBV infection was 9 (V 2001).

f. Corelated gestitional age with hepatitis B infection

This results showed the proportion of gestational age $(<37$ weeks) was 118 people (88.7\%) in cases and 472 people $(88.7 \%)$ in controls with a different proportion of $0 \%$. Gestitional age vaiabel were not statistically significant related to the incidence of hepatitis B virus infection in pregnancy 
with p-value 1.000 . This study is in line with research conducted in 89 case groups. It is known that the age of gestation at delivery is the youngest at 27 weeks and the oldest at 42 weeks. Meanwhile, in this study found 1 case of mother with Hepatitis B at 12 weeks gestation. Similarities with this research is because the respondents were that some pregnant women had already been infected with HBV before this pregnancy so that they had carried out routine antenatal care from the beginning of pregnancy (V, 2001).

The results of this study are different with research conducted by Afzali H, et al. In 2015 on 325 pregnant women in Iran who reported that the risk factors for respondents obtained by almost all respondents were in the third trimester of pregnancy. The difference with this study was because the pregnant women who were sampled were mothers who were hospitalized so that usually patients came with special complaints and for reasons of childbirth.

The high proportion of gestational age at term 37 and $>42$ weeks in this study is due to the fact that screening or screening for every woman who is going to marry has not been fully implemented in all villages, even screening for infections in the first trimester of pregnancy was also not carried out and in the end screening was carried out at delivery or at the time of showing symptoms of the disease. The lack of information on screening for infectious diseases in pregnancy has resulted in a lack of awareness of mothers about health checks before pregnancy planning or early trimester of pregnancy.

Although there is no causal relationship between gestational age and hepatitis B virus infection, the impact of hepatitis $\mathrm{B}$ virus transmission in pregnancy is very dependent on the time when HBV was detected in the mother. Pregnancy will not aggravate the hepatitis virus infection, however, if an acute infection occurs in pregnancy it can cause fulminant hepatitis which can cause high mortality in mothers and babies (Sulaiman, 2006)

According to researchers, gestational age is not directly related to Hepatitis B virus infection, however, the longer the mother is detected, the greater the impact it will have on pregnancy and childbirth and the less treatment the mother receives for hepatitis B virus infection

g. Corelated anemia with hepatitis B infection

This results showed the proportion of pregnant women without anemia cases compared to controls was $7.5 \%$ different with a $\mathrm{p}$ value of 0.04 so that it is close to statistics and OR 0.555 , meaning that $44.5 \%$ of pregnant women without anemia are protected from hepatitis B virus infection compared to mothers with anemia. The results showed that pregnant women with Hepatitis B had the lowest $\mathrm{Hb}$ levels at birth, namely $8.2 \mathrm{~g} \%$ and the highest 15 $\mathrm{g} \%$. Iron deficiency anemia was defined as low serum feretin concentration $<30$ $\mathrm{g} / 1$ and hemoglobin $<11.0 \mathrm{~g} / \mathrm{dl}$ in the first trimester, $<10.5 \mathrm{~g} / \mathrm{dl}$ in the second trimester, and $11.0 \mathrm{~g} / \mathrm{dl}$ in the third trimester. Pregnancy anemia is called "potential danger to mother and child" (potential harm to mother and child).

Anemia suffered by a person can reduce immunity or immunity to various threats of infectious diseases. Pregnant women with anemia are more susceptible to HBV infection than mothers without anemia. Anemia is a common complication of chronic liver disease due to acute and chronic 
gastrointestinal bleeding and secondary hypersplenism due to portal hypertension. Previous studies reported that post partum hemorrhage complications in women with HBV infection appeared to be higher than those with HBsAg (-) that would be followed by anemia, the management of moderate-severe anemia was blood transfusion $(\mathrm{V}, 2001)$. The last studies reported that history of blood transfusion correlates of $\mathrm{HBV}$ infection (OR : 12.59, 95\% CI 1.46-108.89; $\mathrm{p}=$ 0.021 ) its cause virus is transmitted through the blood parenterally into hepatocytes in the form of Dane particles and being the entry points for hepatitis B virus transmission in pregnant women (Noubiap et al., 2015).

Early detection of anemia problems early in pregnancy must be carried out by midwives so that complications such as malnutrition (chronic lack of energy) that have the potential to cause bleeding can be prevented so that medical measures such as blood transfusions, infusions, injection of anti-bleeding drugs that can be the entrance to the Hepatitis B virus can be reduced

h. Corelated abortion history with hepatitis B infection

Result in this study show the proportion of pregnant women without a history of case abortion compared to controls differs $0 \%$ with a $\mathrm{p}$ value of 0.553 so it does not approach statistics. In this study, there were still 9 cases of mothers with a history of previous abortion.. This study is in line with ElKaraksy HM, 2014 which states that risk factors associated with HBV transmission or transmission are history of injections / injections, history of medical examinations, history of hospitalization, history of surgery and history of Hepatitis B (El-karaksy et al., 2014). A history of abortion is one of the risks found in pregnant women in several studies that were treated with medical measures, tissue and a history of blood transfusions. The incidence of abortion was treated with risky medical measures such as curettage, surgical operations of 4 people (26.67\%) which paved the way for HBV infection due to tissue injury (Aj et al., 2015).

This result is not in line with a study in Iran that found $5.72 \%$ of HBV cases in pregnant women with a previous abortion risk (Afzali et al., 2015), a study in China of 15 women with a history of previous abortions $\geq 2$ times. (Cui et al., 2016) As well as research in Indonesia (East Lombok) which found $17.3 \%$ of mothers infected with HBV had had an abortion (Faizaturrahmi et al., 2018). The results of this study are not in line with the 2015 Noubiap study which stated that blood transfusion is one of the variables associated with HBV infection (Noubiap et al., 2015).

The inconsistency of this study with the above research is because the variable blood transfusion in other studies is the direct cause or the main source of hepatitis B virus infection through the blood of individuals who have already suffered from Hepatitis B, while the history of abortion studied in this study is not the main source of hepatitis B virus infection. influenced by other actions such as infusion, injection of anesthesia, use of curettage equipment (sterility of equipment), Hepatitis B status of health workers who perform the action can even be affected by blood transfusions or anemia experienced by the mother. 
A history of previous abortion experienced by a pregnant woman is a risk of entry to the source of Hepatitis B virus infection through various sources of infection such as injection of anesthetic drugs, infusion, administration of blood transfusions if followed by anemia. The application of the principle of sterilization in every medical procedure for pregnant women needs to be increased, especially for pregnant women who have other risk factors such as nutritional disorders and anemia

i. Corelated blood type with hepatitis B infection

Result in this study show the proportion of pregnant women with blood type B was 46 (34.6\%) in cases and $188(35.3 \%)$ in controls, with a difference in proportion of $0.7 \%$. Blood type variable were not statistically significant related to the incidence of hepatitis B virus infection in pregnancy with $\mathrm{p}$-value 1,000 . The results of this study are in line with research conducted at the Harvard School of Public Health which states that the genetics that build blood type $\mathrm{O}$ makes the individual more immune to pancreatic cancer by up to $37 \%$, however, it turns out to be more susceptible to stomach ulcers (Ajeng, 2016).

The blood type a person has is determined by the substances in the blood that are present on the outer surface of the red blood cells in the body. According to researchers, blood group $\mathrm{O}$ does not have immunity to infectious diseases and is susceptible to gastric ulcers which have an impact on gastrointestinal bleeding, thus risking anemia and increasing the risk of being infected with the Hepatitis B virus due to decreased immunity. Further research on the risk of hepatitis B assessed from blood type needs to be done in the future so that promotive and preventive efforts can be made to HBV infection in pregnant women with blood type $\mathrm{O}$

\section{j. Corelated residence with hepatitis $B$} infection

Result of this research show the proportion of pregnant women who came from the urban living environment (in the village of limbung) was 70 people $(52.6 \%)$ in the case and as many as 341 people $(64.1 \%)$ in the control, so the difference in proportion was $11.5 \%$., residence variable were statistically significant related to the incidence of hepatitis B virus infection in pregnancy with p-value 0.020 and OR 1.607 means that pregnant women from the environment around Limbung Village are protected by 1.6 times greater than contracting the Hepatitis B virus than pregnant women who come from the environment outside Limbung Village.

The environment where people with hepatitis B infection in developing countries livemostly come from rural areas. Environment is the third factor contributing to disease, and plays an important role in determining the form of interaction between host / host and agent. The WHO Hepatitis Commission divides the prevalence of hepatitis $\mathrm{B}$ virus infection into 3 groups, namely low, medium and high prevalence. The environment where people with Hepatitis B virus infection in developing countries live mostly come from rural areas (Ugbebor et al., 2011).

The results of the study are not in line with the results of research in Cameroon, $10.2 \%$ of pregnant women with hepatitis B came from rural areas (Noubiap et al. 2015). However, in line with research in Iran, which $82.29 \%$ came from urban areas, statistically this is not directly related to the cause of 
infection transmission (HBV) The high number of respondents who come from areas near to health service sources, especially Sungai Durian Community Health Center makes pregnant women easy reach health facilities so can be diagnosed of Hepatitis B virus infection.

The addition of facilities for rapid diagnostic tests by the government at the Puskesmas and the socialization of the benefits of checking HBsAG status in pregnant women is expected to reduce the risk of HBV transmission. Checking the HbSAg status in groups of people who have an infected population needs to be done considering the horizontal pattern of HBV transmission.

\section{CONCLUSIONS}

The prevalence of Hepatitis B in pregnancy in this research $2.57 \%$. The variables associated with HBV infection were age, parity, LILA, anemia and environment with $\mathrm{p}$ value $<0.05$. Maternal age is the dominant factor associated with HBV infection with OR 1.608 because of the risk of infected HBV through saliva and sperm during sexual intercourse, decreased immunity caused pregnancy and medical treatment that can be the entry points for HBV.

\section{REFERENCES}

Access, O. (2015). Prevalence, sociodemographic features and risk factors of Hepatitis $B$ virus infection among pregnant women in Southwestern Nigeria.

Acholder, 2013. Hubungan Antara Keberadaan DNA Virus Hepatitis B pada Plasenta dan Cairan Amnion Ibu dengan Hepatitis B Antigen Positif Tahun 2013. Bagian Obstetri dan Ginekologi. Fakultas Kedokteran Universitas Hasanudin Makasar.
Afzali, H., Momen Heravi, M., Moravveji, S. A., \& Poorrahnama, M. (2015). Prevalence of Hepatitis B Surface Antigen in Pregnant Women in Beheshti Hospital of Kashan, Isfahan. Iranian Red Crescent Medical Journal, 17(7), 22-26. https://doi.org/10.5812/ircmj.20598v 2.

Aj, G., Po, E., Rc, O., \& Ci, U. (2015). Knowledge and Awareness of Hepatitis B Virus Infection among Pregnant Women in Abakaliki Nigeria. 2(3).

Albiner, 2006. Gizi, Imunitas dan Penyakit Infeksi. Info Kesehatan Masyarakat Volume 10 No 2. www.usu.ac.id.

Anaedobe1 Chinenye Gloria,\&, Adeola Fowotade2, Chukwuma Ewean Omoruyi3, Rasheed Ajani Bakare 2015. Prevalence, socio-demographic features and risk factors of Hepatitis $B$ virus infection among pregnant women in Southwestern Nigeria.

Anna L, 2015. "Perlu Deteksi Dini Hepatitis B pada Ibu Hamil" https://sains.kompas.com/read/2015/04/ 17/150000723/

Bajema, K. L., et al. (2018). Maternal hepatitis $\mathrm{B}$ infection and pregnancy outcomes in the United States: A population-based cohort study.

Borgia G, Carleo MA, Gaeta GB, Gentile I. Hepatitis B in pregnancy. World $\mathrm{J}$ Gastroenterol. 2012;18(34):4677 - 83.

Cui, A., Cheng, X., Shao, J., Li, H., Wang, X., Shen, Y., Mao, L., \& Zhang, S. (2016). Maternal hepatitis B virus carrier status and pregnancy outcomes : a prospective cohort study. BMC 
Pregnancy and Childbirth, 1-8. https://doi.org/10.1186/s12884-0160884-1.

Dari, H. B., \& Ke, I. B. U. (2017). Peraturan menteri kesehatan republik indonesia nomor 52 tahun 2017 tentang eliminasi penularan. 1-84.

Ding, Y., Sheng, Q., Ma, L., \& Dou, X. (2013). Chronic HBV infection among pregnant women and their infants in Shenyang, China. 1-5.

El-Karaksy HM,et al. 2014. Applicability and efficacy of a Model for Prevention of Perinatal Transmission of Hepatitis $B$ Virus Infection: Single Study in Egypt. World Journal of Gastroenterology volume 20.www.ncbi.nlm.nih.gov.

Faizaturrahmi, E., Ani, L.S., Sari, K.A.K. 2018. Risk factors for hepatitis B virus infections among pregnant women in East Lombok District. Public Health and Preventive Medicine Archive 6(2): 108-113.

DOI:10.15562/phpma.v6i2.113.

Franco, E., Bagnato, B., Marino, M. G., Meleleo, C., Serino, L., Zaratti, L., Franco, E., Bagnato, B., \& Vergata, T. (2012). Hepatitis B : Epidemiology and prevention in developing countries. 4(3), 74-80.

https://doi.org/10.4254/wjh.v4.i3.74.

Gozali Ap. (2020). Diagnosis, Tatalaksana, dan Pencegahan Hepatitis B dalam Kehamilan

Hasyimi Muhammad, 2012. Epidemiologi Kebidanan untuk Mahasiswa Kebidanan, Trans Info Medika (TIM). Jakarta
Huang, X., Tan, H., Li, X., Zhou, S., Wen, S. W., \& Luo, M. (2014). Maternal chronic HBV infection would not increase the risk of pregnancy-induced hypertension - Results from pregnancy cohort in Liuyang Rural China. PLoS ONE, $\quad 9(12), \quad 1-11$. https://doi.org/10.1371/journal.pone.01 $\underline{14248}$

Ismiyati, 2019. Penularan Infeksi Hepatitis B Pada Ibu Hamil (Transmission of Hepatitis B virus in Pregnant Women).https://www.researchgate.net/ publication $/ 33313176$

Kementrian Kesehatan Republik Indonesia, 2019. 1,5 juta lebih ibu hamil di deteksi Hepatitis

B. https://www.kemkes.go.id/article/view/ 19072300002/1-5-juta-lebih-ibu-hamildideteksi-dini hepatitis-b.html

Kes, M Hardhana et al. (2019). Profil Kesehatan Republik Indonesia Tahun 2019.

Kolawole, O. M., Wahab, A. A., Adekanle, D. A., Sibanda, T., \& Okoh, A. I. (2012). Seroprevalence of hepatitis B surface antigenemia and its effects on hematological parameters in pregnant women in Osogbo , Nigeria. Virology Journal, $9(1), \quad 1$. https://doi.org/10.1186/1743-422X$\underline{9-317 .}$

Lapau Buchari, 2009. Prinsip dan Metode Epidemiologi Cetakan Pertama, Badan Penerbit FKUI.Jakarta.

Lesmana, n.d, 2006. Panduan Tatalaksana Infeksi Hepatitis B Kronis. Konsensus Perhimpunan Peneliti 
Hati Indonesia.Jakarta.www.pphionline.org.

Mandal K , 2006. Penyakit Infeksi Edisi Keenam, Erlangga. Jakarta.

Noubiap, J. J. N., Nansseu, J. R. N., Ndoula, S. T., \& Bigna, J. J. R. (2015). Prevalence, infectivity and correlates of hepatitis $B$ virus infection among pregnant women in a rural district of the Far North Region of Cameroon. 17. https://doi.org/10.1186/s12889-0151806-2.

Syafiq , 2009. Gizi dan Kesehatan Masyarakat, Raja Grafindo Persada . Jakarta

Setyohadi, Bambang dkk, 2016. Kegawatdaruratan Penyakit Dalam (Emergency In Internal Medicine). Pusat Penerbitan Ilmu Penyakit Dalam. Jakarta

Sulaiman, 2006. Pendekatan Terkini Hepatitis B dan C dalam Praktik Klinis sehari-hari. Sagung Seto, Jakarta.

Ugbebor Ose, 2011. The prevalence of hepatitis $B$ and $C$ viral infections among pregnant women at the University of Benin Teaching Hospital (UBTH) located in the heart of Benin City, Edo state Nigeria tahun 2009-2010. www.ncbi.nlm.nih.gov

V , 2001. Pengelolaan hepatitis B dalam kehamilan dan persalinan [Thesis]. Semarang: Obstetri dan Ginekologi Fakultas Kedokteran Universitas Diponegoro Semarang; Notoatmodjo, S. 2012. Metodologi Penelitian Kesehatan. Jakarta : Rineka Cipta

Wijayanti, 2016. Efektivitas HBsAg - Rapid Screening Test Untuk Hepatitis B pada Mahasiswi Prodi D-III
Kebidanan STIKes Kusuma Husada Surakarta Bulan Januari-Maret 2015. Jurnal Kesmadaska. www.stikeskusumahusada.ac.id 